\title{
RE-APPRAISAL OF THE SANTA RITA GREENSTONE BELT STRATIGRAPHY, CENTRAL BRAZIL, BASED ON NEW U-PB SHRIMP AGE AND SM-ND DATA OF FELSIC METAVOLCANIC ROCKS
}

\section{MÁRCIO MARTINS PIMENTEL ${ }^{1}$, HARDY JOST ${ }^{1}$, RICHARD ARMSTRONG ${ }^{2}$, REINHARDT ADOLFO FUCK ${ }^{1}$, SÉRGIO LUIZ JUNGES ${ }^{1}$ AND MARCELO GONÇALVES RESENDE ${ }^{3}$}

\begin{abstract}
The Santa Rita greenstone belt represents one of the supracrustal belts of the Archaean terranes of Goiás, central Brazil. The stratigraphic sequence of this greenstone belt comprises a lower unit made of komatiites and basalts and an upper metasedimentary unit made of carbonaceous schist, chert, iron formation and marble, unconformably overlain by clastic metasedimentary rocks. Felsic metavolcanics occur at the interface between the metabasalts and the upper metasedimentary pile. U-Pb SHRIMP age for zircons from the felsic metavolcanics reveal that it is not part of the Archaean sequence, but represents the product of a Mesoproterozoic (1580 $\pm 12 \mathrm{Ma})$ magmatic event. Sm-Nd isotopic data (initial $\mathrm{e}_{\mathrm{CHR}}$ values between -10.5 and -14.9) and $\mathrm{T}_{\mathrm{PM}}$ values of 3.0 and $3.2 \mathrm{Ga}$, within the range of the surrounding TTG terranes, indicate that the original felsic magmas were produced by re-melting of Archaean crust. The data demonstrate that the Goiás greenstone belt contains infolded and imbricated Proterozoic rocks, as previously suggested by Sm-Nd isotopic analyses of some of the upper detrital metasedimentary rocks.
\end{abstract}

Keywords: Goiás, Greenstone Belts, U-Pb SHRIMP, stratigraphy

INTRODUCTION The Santa Rita greenstone belt (Danni et al. 1981), or Goiás greenstone belt of Resende et al. (1998), is one of the low grade metamorphic supracrustal rock assemblages of the Archaean terranes of Goiás, central Brazil (Fig. 1). It is approximately $65 \mathrm{~km}$ long and, in average, $7 \mathrm{~km}$ wide. It consists of a large $\mathrm{N} 50^{\circ}-70^{\circ} \mathrm{W}$ trending syncline (Fig. 2) confined between the Caiçara and Uvá granitoid complexes (Jost et al. 2000). To the northwest, it is in contact with the Faina greenstone belt by a northeast-trending strike-slip fault. To the southeast, Paleoproterozoic metasedimentary rocks overthrust the Santa Rita belt.

The stratigraphic sequence of the belt (Fig. 2) consists of lower metakomatiites followed by tholeiitic metabasalts, and an upper metasedimentary package including, from base to top, carbonaceous schist, chert, iron formation and marble, unconformably overlain by metarhythmites. For almost two decades (see, for example, Danni et al. 1981), a dacitic volcanic center has been traditionally interpreted as part of the stratigraphic sequence. The aim of this paper is to show, based on U-Pb SHRIMP age of zircons, that the felsic volcanic rocks do not belong to the Archaean supracrustal sequence, but to a so far unknown Mesoproterozoic volcanic episode.

PREVIOUS STRATIGRAPHIC NOMENCLATURE Danni $e t$ al. (1981) first interpreted the Santa Rita greenstone belt as consisting of Archaean supracrustal rocks (Serra de Santa Rita Sequence), overlain by Proterozoic metasedimentary rocks (Serra do Cantagalo Sequence). The Serra de Santa Rita Sequence was further subdivided into a lower unit consisting of ultramafic metavolcanics, an intermediate unit of mafic and felsic metavolcanic rocks, and an upper unit of metasedimentary rocks. The Serra do Cantagalo Sequence was described as consisting of metaconglomerates and quartzites overlain by metadolomites and banded iron formations. The presence of clasts of mafic and ultramafic rocks in the metaconglomerates supported the conclusion that the source area is the underlying Archaean rocks. The Serra do Cantagalo Sequence would then rest on the greenstone belt by means of an erosional unconformity.

Teixeira (1981) suggested that the rocks of the greenstone belt should be considered as the Goiás Velho Group. The group was informally subdivided into a basal unit (ultramafic metavolcanics), an intermediate unit (mafic and felsic metavolcanics), and an upper unit (metasedimentary rocks), which included the Serra do Cantagalo Sequence of Danni et al. (1981). Later, Tomazzoli (1985) and Tomazzoli \& Nilson (1986) subdivided the Goiás Velho Group into three units. The basal or lower ultramafic unit consists of metakomatiites with local spinifex texture and intercalations of ironrich metachert, graphitic phyllite, and metapelite. The intermediate or basic unit consists of mafic metavolcanics and felsic metatuffs with intercalations of metachert, graphitic phyllite, and metapelite. The upper or metasedimentary unit includes metapelites, locally graphitic, with minor metachert, banded iron formation, and marble. The authors

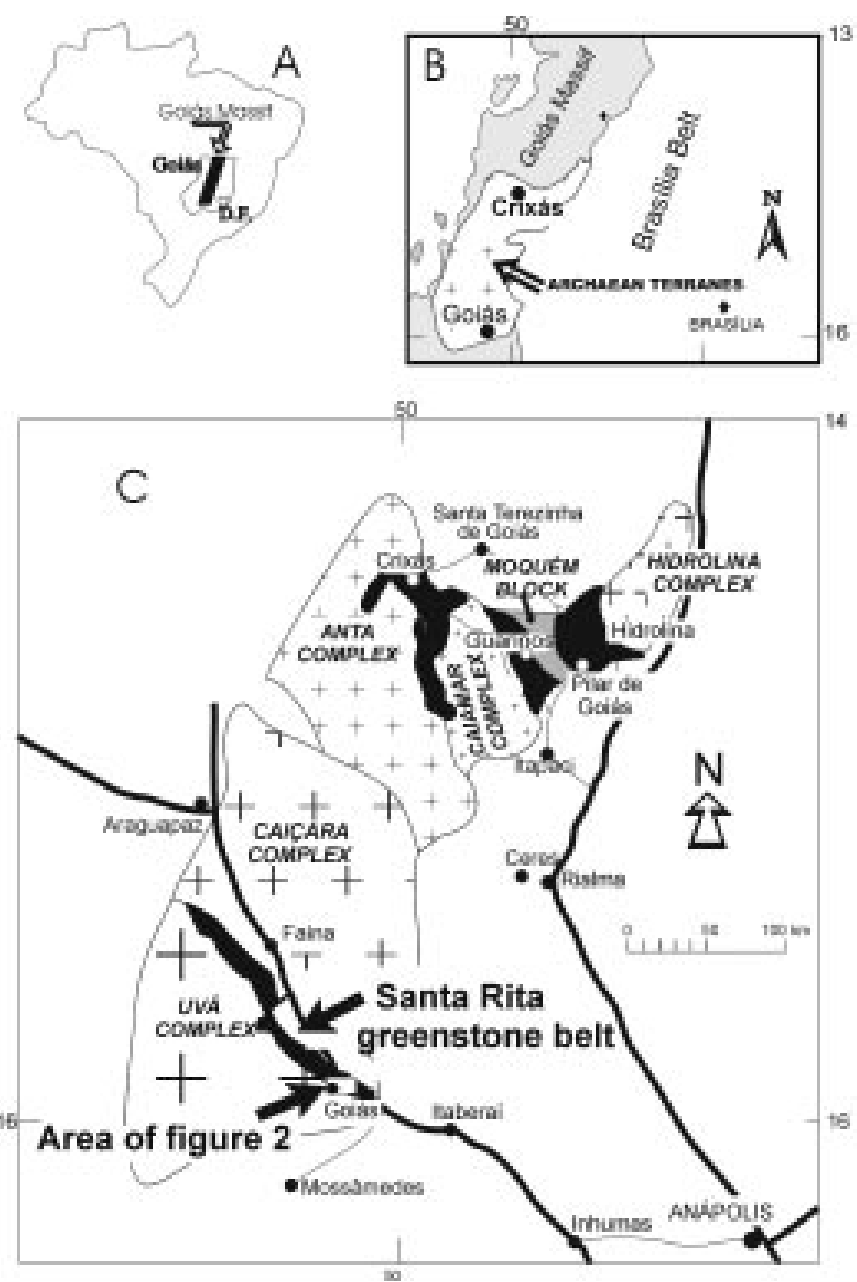

Figure 1 - Geographic location and geologic setting of the Santa Rita greenstone belt, Central Brazil.

included the Serra do Cantagalo Sequence into the upper unit, subdividing it into lower metaconglomerates, quartzites and metapelites, and upper metagraywackes with rhythmic intercalations of metapelite and quartzite.

Recently, Resende (1998) and Resende et al. (1998) put forward a formal stratigraphic nomenclature (Fig. 2) for the Santa Rita greenstone belt. Under this model, the lower metavolcanic rocks

1 - Instituto de Geociências, Universidade de Brasília, 70919-970 - Brasília, DF, Brazil, e-mail: marcio@unb.br

2 - Research School of Earth Sciences, The Australian National University, Canberra, Australia, ACT 0200.

3 - Universidade Católica de Brasília - Curso de Graduação em Engenharia Ambiental e Mestrado em Gestão e Planejamento Ambiental 


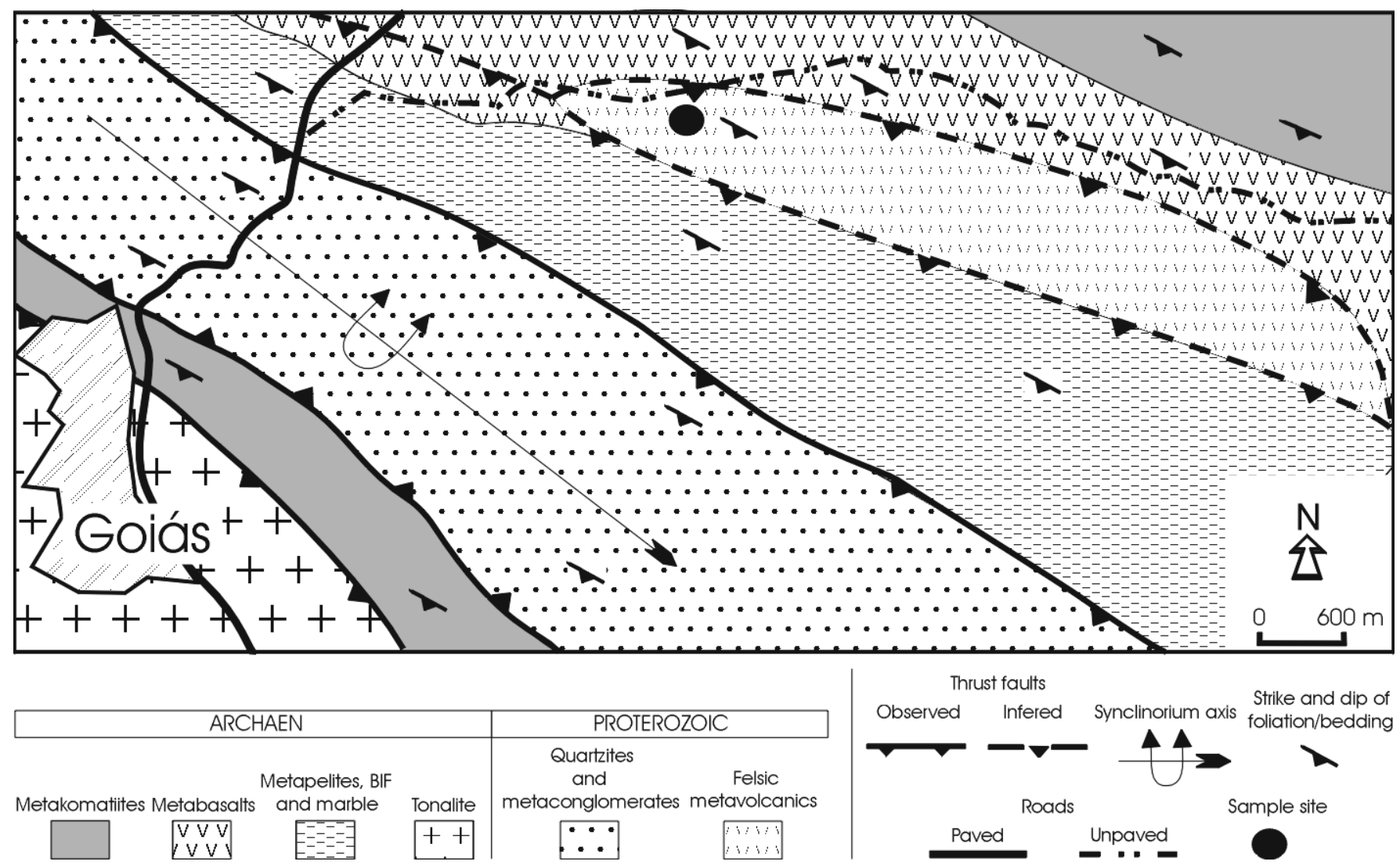

Figure 2 - Detail of the Santa Rita greenstone belt in the vicinities of the felsic volcanic unit (modified from Promo 1993).

comprise the Serra de Santa Rita Group, subdivided, from base to top, into the Manoel Leocádio and Digo-Digo Formations. The former consists of about $600 \mathrm{~m}$ of metakomatiites with minor oxide-facies banded iron formations. The latter contains a lower and an upper member. The lower member (up to 1,000 m thick) consists of tholeiitic metabasalts with minor intercalations of banded iron formations and, towards the top, also carbonaceous schists. The upper member consists of about $200 \mathrm{~m}$ thick of felsic metatuffs with minor intercalations of metachert, locally rich in pyrite.

Tomazzoli (1985) and Resende et al. (1998) describe that the contact between the felsic metavolcanic rocks and the underlying metabasalts is gradational, and given by an approximately $100 \mathrm{~m}$ thick section with intercalations of rocks of both units. Resende et al. (1998) describe that the felsic volcanics are laterally interfingered with carbonaceous schists of the lower sections of the upper metasedimentary sequence. These arguments led to interpret the felsic volcanic rocks are an intimate part of the stratigraphic sequence of the Santa Rita greenstone belt. They would represent an eruptive event of the final stages of the basaltic volcanism and coeval with the onset of the upper sedimentary unit. Therefore, the Santa Rita greenstone belt volcanism was interpreted as typically bimodal, a feature not observed in any of the other Archaean belts of Goiás.

\section{MAIN CHARACTERISTICS OF THE FELSIC}

METAVOLCANICS The felsic metavolcanics occur as a ca. $5 \mathrm{~km}$ long lens, with a maximum width of $200 \mathrm{~m}$, situated near the core of the Santa Rita greenstone belt synclinorium. They consist mostly of sericite-chlorite-quartz schists with relicts of original pyroclastic textures varying from recrystallized ash to coarse tuffs, including abundant layers with lapilli-size fragments. Their composition is dominantly dacitic with minor thin rhyolitic terms.

The metadacites contain millimetric plagioclase phenocrysts in a fine-grained groundmass of quartz, sericite, chlorite, and biotite. Microcline, magnetite, ilmenite, epidote, titanite, apatite, rutile are accessory, and zircon is rare. Leucoxene and carbonate are secondary minerals. In general, the lapilli fragments have the same mineralogical composition as the matrix.
U-Pb and Sm-Nd ISOTOPIC RESULTS U-Pb analyses were carried out using the SHRIMP-II (Sensitive High Resolution Ion Microprobe) at the Research School of Earth Sciences of the Australian National University, Canberra. In order to assess the internal structure of the zircons, cathodoluminescence (CL) imaging of the zircon concentrates was carried out before isotopic analyses. The sample investigated (GOV-2) corresponds to a porphyritic metadacite. Zircons are pink and form euhedral prismatic crystals. CL images did not reveal obvious cores or overgrowths. Twelve spots were analyzed (Table 1) and nine analytical points plot close to the concordia curve defining the upper intercept age of $1580 \pm 12 \mathrm{Ma}(\mathrm{MSWD}=0.9)$ (Fig. 3 ). The spots analyzed correspond to parts of the crystals displaying thin zoning alternating high- and low-U areas, characteristic of magmatic zircons. This age is interpreted as the crystallization age of the original felsic volcanic rock.

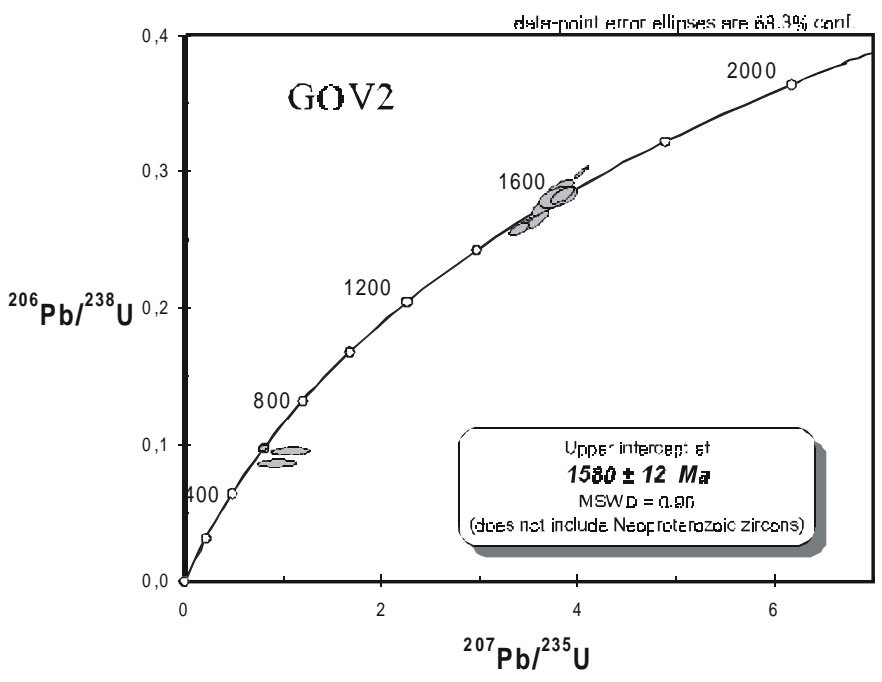

Figure 3 - Concordia diagram for sample GOV-2 
Table 1 - Summary of SHRIMP U-Th-Pb zircon results of sample GOV-2

\begin{tabular}{|c|c|c|c|c|c|c|c|c|c|c|c|c|c|c|c|c|c|c|c|}
\hline \multirow{3}{*}{$\begin{array}{c}\text { Grain. } \\
\text { spot }\end{array}$} & \multirow{3}{*}{$\begin{array}{c}\mathrm{U} \\
(\mathbf{p p m})\end{array}$} & \multirow{3}{*}{\multicolumn{2}{|c|}{$\begin{array}{l}\text { Th } \\
\text { (ppm) }\end{array}$}} & \multirow{3}{*}{$\begin{array}{l}\text { Th/U } \\
\text { (ppm) }\end{array}$} & \multirow{3}{*}{$\begin{array}{l}{ }^{204} \mathrm{~Pb} / \\
{ }^{206} \mathrm{~Pb}\end{array}$} & \multirow{3}{*}{$\begin{array}{c}f_{206} \\
\%\end{array}$} & \multirow{3}{*}{$\begin{array}{l}{ }^{206} \mathrm{~Pb} / \\
{ }^{238} \mathrm{U}\end{array}$} & & \multicolumn{4}{|c|}{ Radiogenic Ratios } & \multicolumn{6}{|c|}{ Ages (in Ma) } & \multirow{3}{*}{$\begin{array}{c}\text { Conc. } \\
\%\end{array}$} \\
\hline & & & & & & & & & \multicolumn{2}{|c|}{${ }^{207} \mathrm{~Pb} /$} & \multicolumn{2}{|c|}{${ }^{207} \mathrm{~Pb} /$} & \multicolumn{2}{|c|}{${ }^{206} \mathrm{~Pb} /$} & \multicolumn{2}{|c|}{${ }^{207} \mathrm{~Pb} /$} & \multicolumn{2}{|c|}{${ }^{207} \mathrm{~Pb} /$} & \\
\hline & & & & & & & & & ${ }^{235} \mathbf{U}$ & \pm & ${ }^{206} \mathrm{~Pb}$ & \pm & ${ }^{238} \mathbf{U}$ & \pm & ${ }^{235} \mathbf{U}$ & \pm & ${ }^{206} \mathrm{~Pb}$ & \pm & \\
\hline 1,1 & 1517 & 1490 & 0,98 & 540 & 0,000003 & 0,00 & 0,3002 & 0,0033 & 4,046 & & 0,0977 & & 1693 & 16 & 1644 & 10 & 1582 & 6 & 107 \\
\hline 2,1 & 67 & 890 & & 247 & 00024 & & 44 & & & & & & 1613 & 16 & 1602 & 10 & 1587 & 6 & 102 \\
\hline 4,1 & 376 & 383 & & 28 & & & & & & & & & 610 & & & & 592 & & 01 \\
\hline 5,1 & 104 & 102 & & 3 & & & 771 & & 697 & & & & 1577 & & 1571 & & 563 & & 101 \\
\hline 6,1 & 498 & 389 & 0,78 & 60 & 23046 & 3,32 & 0975 & & 107 & & & & 600 & & 757 & & 253 & 246 & 48 \\
\hline 6,2 & 212 & 256 & 101 & 24 & 6064 & 83 & 0,0884 & & 979 & & & & 546 & 1 & 693 & & 205 & 277 & 45 \\
\hline 7,1 & 80 & 65 & & 2 & 00248 & & 0,2876 & & 818 & & & & 1629 & & 1597 & & 1554 & & 105 \\
\hline 8,1 & 44 & 4 & & 1 & 00389 & & 2825 & & 809 & & & & 1604 & & 1595 & & 1583 & & 101 \\
\hline 9,1 & 223 & 143 & & 64 & 00196 & 0,3 & 0,2606 & & 3,458 & & & & 1493 & 18 & 1518 & & 1552 & & 96 \\
\hline 10,1 & 204 & 217 & 1,06 & 25 & 000648 & 1,03 & 0,1001 & & 0,836 & & & & 615 & 8 & 617 & & 626 & 77 & 98 \\
\hline 11 , & 105 & 81 & & 3 & 00099 & & 0,2655 & & 3,599 & & & & 1518 & 22 & 15 & & 1592 & & 95 \\
\hline & 16 & 226 & & 13 & & & 2839 & & 3,876 & & & & 1611 & 1 & 16 & & 1606 & & 100 \\
\hline 12,1 & 102 & 85 & 0,83 & 30 & 0,000688 & 1,10 & 0,2590 & 0,0032 & 3,414 & 0,067 & 0,0956 & 0,0013 & 1485 & 16 & 1508 & 16 & 1540 & 26 & 96 \\
\hline
\end{tabular}

1. Uncertainties given at the one ? level.

2. $\mathrm{f}_{206} \%$ denotes the percentage of ${ }^{206} \mathrm{~Pb}$ that is common $\mathrm{Pb}$.

3. Correction for common $\mathrm{Pb}$ made using the measured ${ }^{204} \mathrm{~Pb} /{ }^{206} \mathrm{~Pb}$ ratio.

4. For $\%$ Conc., $100 \%$ denotes a concordant analysis.

Zircon 10.1 yielded a concordant analysis at $615 \mathrm{Ma}\left({ }^{206} \mathrm{~Pb} /{ }^{238} \mathrm{U}\right.$ age), indicating recrystallization during the Brasiliano/Pan-African orogeny. Two other analyses of one crystal also show the effect of the Neoproterozoic thermal event (spots 6.1 and 6.2 in Table 1). The high ${ }^{204} \mathrm{~Pb} /{ }^{206} \mathrm{~Pb}$ ratios of these analyses, however, render poorly defined ${ }^{206} \mathrm{~Pb} /{ }^{238} \mathrm{U}$ ages of 600 and $546 \mathrm{Ma}$, respectively (Table 1). Brasiliano zircons have also been found in orthogneisses of the surrounding TTG terranes in the Goiás and Crixás areas, demonstrating the influence of the Neoproterozoic thermal event in the Archaean terranes of Goiás (Queiroz et al. 1999, Pimentel, unpublished results).

$\mathrm{Sm}-\mathrm{Nd}$ isotopic analyses were performed on two whole-rock samples of the felsic metavolcanic rocks of the Santa Rita greenstone belt (Table 2). Analyses were carried out at the geochronology laboratory of the Universidade de Brasília.

Table 2 - Sm-Nd isotopic results of felsic metavolcanics of the Santa Rita greenstone belt.

\begin{tabular}{|c|c|c|c|c|c|c|}
\hline Sample & $\mathrm{Sm}(\mathrm{ppm})$ & $\mathrm{Nd}(\mathrm{ppm})$ & ${ }^{147} \mathrm{Sm} /{ }^{144} \mathrm{Nd}$ & ${ }^{143} \mathrm{Nd} /{ }^{144} \mathrm{Nd}( \pm 1 \sigma)$ & $\mathrm{T}_{\mathrm{DM}}(\mathrm{Ga})$ & $\varepsilon_{\mathrm{Nd}}(\mathrm{T})$ \\
\hline GOV-2 & 3.810 & 18.21 & 0.1198 & $0.511079(15)$ & 3.21 & -14.9 \\
GOV-3 & 3.328 & 15.47 & 0.1307 & $0.511416(20)$ & 3.00 & -10.5 \\
\hline
\end{tabular}

Samples GOV-2 and GOV-3 yielded $\mathrm{T}_{\mathrm{DM}}$ model ages of 3.0 and $3.2 \mathrm{Ga}$, and $\varepsilon_{\mathrm{Nd}}(\mathrm{T}=1.58 \mathrm{Ga})$ of -14.9 and -10.5 , respectively, indicating that the original magma was the product of re-melting of Archaean crust (Fig. 4). Therefore, this magmatic event represents a Mesoproterozoic episode of continental crust reworking. The $\mathrm{T}_{\mathrm{DM}}$ values are within the range defined by the orthogneisses surrounding the Goiás greenstone belt (3.0-3.5 Ga; Pimentel et al. 1996, and unpublished results).

DISCUSSION AND CONCLUSIONS A first set of evidence that the Santa Rita greenstone belt syncline contains infolded and imbricated Proterozoic rocks, particularly within the core of the structure, was presented by Resende et al. (1998) and Resende (1999). The authors describe convincing relationships between the wellpreserved primary sedimentary structures of metaconglomerates, quartzites of the Serra do Cantagalo Sequence, and the syncline delineated by the Archaean supracrustal rocks. According to these relationships, the Serra do Cantagalo Sequence was thrusted into the domain of the older supracrustal rocks, both folded during a later event, the preserved section of the younger rocks being overturned respectively to the older ones. Additionally, Sm-Nd model ages $\left(\mathrm{T}_{\mathrm{DM}}\right)$ across the siliciclastic rock sequence of the upper stratigraphic units vary from 3.1 to $2.8 \mathrm{Ga}$. This contrasts with the $2.3 \mathrm{Ga} \mathrm{Sm}-\mathrm{Nd}$ model age of the matrix of metaconglomerates of the Serra do Cantagalo Sequence, indicating that this indicates that this unit is not Archaean,

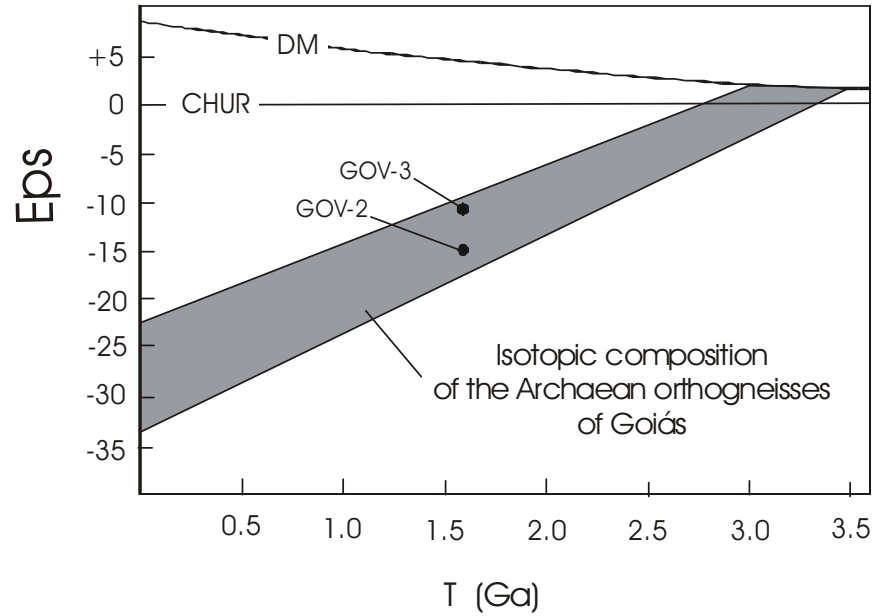

Figure 4 - Nd isotopic composition of the felsic metavolcanic rocks.

but, at the most, Palaeoproterozoic. These data, combined with the results of the present study, clearly indicate that the Santa Rita greenstone belt does not contain only Archaean supracrustal rocks, as previously inferred, but even Proterozoic supracrustal rocks as thrusted and imbricated slices. The detailed structural relationships between the younger and older rocks remain to be more clearly explained, but it probably happened during the Brasiliano (Neoproterozoic) deformation. Jost et al. (1996), Fortes (1996), Queiroz and Jost (1998) and Queiroz et al. (1999) describe similar situations in the three greenstone belts in the northern section of the Archaean terranes of Goiás. This leads to the conclusion that the greenstone belts of Goiás underwent pronounced structural and stratigraphic modifications, with conspicuous mixing with rock units belonging to Paleo-, Meso- and Neoproterozoic event, raising enormous difficulties in unraveling the original Archaean sequences.

On the other hand, the U-Pb SHRIMP age of the felsic volcanics of the Santa Rita greenstone belt is not fully understood in regional terms. Rocks of this age are not common in the basement of the Brasília Belt. The only examples are the alkali-rich. A-type granites of the Rio Tocantins sub-province of the Goiás Tin Province, with $\mathrm{U}-\mathrm{Pb}$ and $\mathrm{Pb}$ $\mathrm{Pb}$ ages between 1560 and $1600 \mathrm{Ma}$ (Pimentel et al. 1991). However, preliminary geochemical data for the Goiás greenstone belt volcanic rocks presented by Tomazzoli (1985) suggest that they have a calcalkaline affinity, and are not comparable geochemically to the granitic magmatism in the Goiás tin province. This observation supports the current idea that the Archaean terranes of Goiás are allochtonous with 
respect to the tectonic evolution of the Brasília Belt, being accreted to its western margin towards the end of the Neoproterozoic.

Acknowledgements To Conselho Nacional de Desenvolvimento Científico e Tecnológico - CNPq for a Research Grant to H. Jost
(Proc. $\mathrm{n}^{\mathrm{o}} 35.1597 / 97-2$ ), and for funding part of the field works (Proc. $\mathrm{n}^{\mathrm{o}} 52.0682 / 94$ ), to two anonymous referees of RBG for their critical review of the manuscript and helpful suggestions. To FAP-DF (Proc. $\mathrm{N}^{\mathrm{o}}$ 193.000.068/96) and CAPES for funding field and laboratory work.

\section{References}

Danni J.C.M., Dardenne M.A., Fuck R.A. 1981. Geologia da região da Serra da Santa Rita e Sequiência Serra de Cantagalo: Simpósio de Geologia do Centro-Oeste, 1, Goiânia, Anais..., p. 265-280.

Fortes, P.T.F.O. 1996. Metalogênese dos depósitos auríferos Mina III, Mina Nova e Mina Inglesa, Greenstone Belt de Crixás, GO. Unpublished PhD Thesis, Instituto de Geociências, Universidade de Brasília, 176pg.

Jost H., Figueiredo A.M.G., Ferreira A.V. 1996. Are all detrital metasedimentary rocks of the Crixás Greenstone Belts Archean and of the same provenance? A discussion based on REE geochemistry. Symposium Archean of the South American Platform, I, Brasília, Extended Abstracts, p. 44-46.

Jost H., Resende M.G., Osborne G.A., Queiroz C.L., Blum M.L.B., Pires A.C.B., Moraes R.A.V. 2000. O Arqueano do Estado de Goiás. In: Hasui, Y. \& Sena Costa, J.B. (edit.) Geotectônica do Brasil, (submitted)

Pimentel M.M., Heaman L., Fuck R.A., Marini O.J. 1991. U-Pb zircon geochronology of Precambrian tin-bearing continental-type acid magmatism in central Brazil. Precamb. Research,52:321-335.

Pimentel M.M., Fuck R.A., Silva J.L.H. 1996. Dados Rb-Sr e Sm-Nd da região de JussaraGoiás-Mossâmedes (GO), e o limite entre terrenos antigos do Macico de Goiás e o Arco Magmático de Goiás. Revista Brasileira de Geociências, 26:61-70

Queiroz C.L and Jost H. 1998. Polycyclic deformation on an Archean crustal segment of the Goiás Mnassif, Central Brazil. $14^{\text {th }}$ International Conference of Basement Tectonics, Proceedings..., p. 166-169
Queiroz C.L., Jost H., McNaughton N.J. 1999. U/Pb - SHRIMP ages of Crixás greenstone belt terranes: from Archaean to Neoproterozoic. SBG, Simpósio Nacional de Estudos Tectônicos, 7, Anais..., p. 35-37

Resende M.G., Jost H., Osborne G.A., Mol A. 1998. The stratigraphy of the Goiás and Faina greenstone belts, Central Brazil: a new proposal. Revista Brasileira de Geociências 28:77-94

Resende M.G. 1999. Fundamentos para o estudo da evolução das supracrustais metassedimentres da região de Goiás e Faina, Goiás. Unpublished Ph.D. Thesis, Universidade de Brasília.

Teixeira A.S. 1981. Geologia da região de Goiás-Faina: Simpósio de Geologia Centro-Oeste, Anais.... Goiânia, p. 344-360.

Tomazzoli E.R. and Nilson A.A. 1986. Contribuição à geologia, metamorfismo e deformação do Greenstone Belt de Goiás, GO: Congresso Brasileiro Geologia, 34, Goiânia, Anais...., v. 2 p.615-629.

Tomazzoli E.R. 1985. Geologia, Petrologia, deformação e potencial aurífero do greenstone belt de Goiás - GO. Unpublished Masters Thesis, Universidade de Brasília, 206p.

Contribution IGC-176

Received March 8, 2000 Accepted for publication April 26, 2000 